Published in final edited form as:

Semin Immunol. 2011 August ; 23(4): 252-263. doi:10.1016/j.smim.2011.06.007.

\title{
Tolerogenic dendritic cells and their role in transplantation
}

\author{
Mohamed Ezzelarab ${ }^{\mathrm{a}}$ and Angus W. Thomson ${ }^{\mathrm{a}, \mathrm{b},{ }^{*}}$ \\ aThomas E. Starzl Transplantation Institute, Department of Surgery University of Pittsburgh \\ School of Medicine, 200 Lothrop Street, BST W1540, Pittsburgh, PA 15261, USA \\ ${ }^{b}$ Department of Immunology, University of Pittsburgh School of Medicine, 200 Lothrop Street, \\ BST W1540, Pittsburgh, PA 15261, USA
}

\begin{abstract}
The pursuit of clinical transplant tolerance has led to enhanced understanding of mechanisms underlying immune regulation, including the characterization of immune regulatory cells, in particular antigen-presenting cells (APC) and regulatory T cells (Treg), that may play key roles in promoting operational tolerance. Dendritic cells (DC) are highly-efficient APC that have been studied extensively in rodents and humans, and more recently in non-human primates. Owing to their ability to regulate both innate and adaptive immune responses, DC are considered to play crucial roles in directing the alloimmune response towards transplant tolerance or rejection. Mechanisms via which they can promote central and peripheral tolerance include clonal deletion, the induction of Treg, and inhibition of memory $\mathrm{T}$ cell responses. These properties have led to the use of tolerogenic DC as a therapeutic strategy to promote organ transplant tolerance. In rodents, infusion of donor- or recipient-derived tolerogenic DC can extensively prolong donor-specific allograft survival, in association with regulation of the host $\mathrm{T}$ cell response. In clinical transplantation, progress has been made in monitoring DC in relation to graft outcome, including studies in operational liver transplant toleranceAlthough clinical trials involving immunotherapeutic DC for patients with cancer are ongoing, implementation of human DC therapy in clinical transplantation will require assessment of various critical issues. These include cell isolation and purification techniques, source, route and timing of administration, and combination immunosuppressive therapy. With ongoing non-human primate studies focused on DC therapy, these logistics can be investigated seeking the optimal approaches. The scientific rationale for implementation of tolerogenic DC therapy to promote clinical transplant tolerance is strong. Evaluation of technical and therapeutic logistic issues is an important next step prior to the application of "therapeutic" DC in clinical organ transplantation.
\end{abstract}

\section{Keywords}

dendritic cells; antigen presentation; T cells; T regulatory cells; tolerance; transplantation

\footnotetext{
(C) 2011 Elsevier Ltd. All rights reserved

*Corresponding author at: Thomas E. Starzl Transplantation Institute Angus W. Thomson PhD, DSc University of Pittsburgh 200 Lothrop Street, W1540 BST Pittsburgh, PA 15261, USA Telephone: 412-624-6392 Fax: 412-624-1172 thomsonaw@upmc.edu.

Publisher's Disclaimer: This is a PDF file of an unedited manuscript that has been accepted for publication. As a service to our customers we are providing this early version of the manuscript. The manuscript will undergo copyediting, typesetting, and review of the resulting proof before it is published in its final citable form. Please note that during the production process errors may be discovered which could affect the content, and all legal disclaimers that apply to the journal pertain.
} 


\section{Introduction}

Reduced dependence on immunosuppressive drug therapy and the induction of donor specific tolerance are major objectives for numerous studies aimed at improving clinical outcomes in transplantation. Much recent research has focused on better understanding of the cellular and molecular mechanisms underlying immune regulation, as well as exploring novel therapies to induce donor-specific tolerance. In recent years, considerable interest has focused on the prospective value of targeting specific immune regulatory cells (that include dendritic cells [DC], regulatory T cells [Treg], and myeloid-derived suppressor cells) or exploiting these cell populations to promote the long sought-after goal of clinical transplant tolerance.

DC are rare, uniquely well-equipped, functionally-diverse professional antigen (Ag)presenting cells (APC) that are regarded as key instigators and regulators of innate and adaptive immunity. They play major roles in directing the immune response towards tolerance or immunity. DC are the best-characterized APC in the context of organ transplantation, where that favor graft acceptance are considered tolerogenic (tol DC), and those that induce graft rejection are viewed as immunogenic. Over the past two decades, beginning with recognition of their role in intra-thymic tolerance [1,2], DC with tolerogenic properties have been studied extensively in small animal models and in human in vitro systems. Detailed background literature on both mouse and human tol DC and their relation to regulation of alloimmunity and the outcome of organ transplantation has been reviewed in [3-9]. Due to their inherent tolerogenicity, DC are considered potential therapeutic targets or cellular agents (negative cellular vaccines) in transplantation and autoimmune disease [1012], contrasting with their potential immunostimulatory properties as anti-cancer vaccines [13]. While in numerous experimental animal models, DC have proved to be effective tolerogenic APC, the current challenge is whether these benefits can be translated into effective strategies to promote transplant tolerance in humans (Figure 1).

\section{Phenotypic and functional characteristics of DC}

DC constitute a heterogeneous rather than a discrete cell population, that arises from CD34 ${ }^{+}$ cells within the bone marrow (BM). They are found both in the thymus and secondary lymphoid tissue, in the circulation, in peripheral tissues such as skin, mucosal surfaces, intestine, lung, liver, and in maternal decidua. As APC, they are specialized in Ag capture, processing, and presentation; upon activation (as occurs following organ transplantation), they display enhanced capacity to migrate from the periphery via afferent lymph or blood to regional lymphoid tissues, where they interact with $\mathrm{T}$ cells and regulate their function.

Multiple DC subsets have been described in various tissues, especially the spleen [14, 15], since the first description of myeloid DC in mouse spleen by Steinman and Cohn in 1973/74 $[16,17]$. In humans, the two major and intrinsically distinct subpopulations of DC are the "conventional" myeloid DC (mDC) and plasmacytoid DC (pDC). $\mathrm{mDC}$ and $\mathrm{pDC}$ are distinguished by both cell surface markers and function [18, 19]. Under inflammatory conditions, and following Toll-like receptor (TLR) ligation and Ag uptake (e.g. pathogen or donor alloAg), $\mathrm{mDC}$ migrate to $\mathrm{T}$ cell areas of secondary lymphoid tissue to initiate adaptive immunity. On the other hand, pDC that express a genetic profile more closely resembling lymphoid cell development [20], recognize nucleic acids (both microbial and self) and produce interferon (IFN)- $\alpha$, an important component of innate immune responses. Tolerogenic properties of both $\mathrm{mDC}$ and $\mathrm{pDC}$ (mouse and human) have been reported extensively, including the capacity of human $\mathrm{mDC}$ to induce Ag-specific tolerance in vivo, in healthy volunteers [21, 22]. 
Generally, human DC have been identified as major histocompatibility complex (MHC) class $\mathrm{II}^{+}\left(\mathrm{HLA}-\mathrm{DR}^{+}\right)$cells in peripheral tissues. In the circulation, they are lineage negative $\left(\mathrm{Lin}^{-}\right)$and express blood DC Ags (BDCA); while $\mathrm{mDC}$ are $\mathrm{Lin}^{-} / \mathrm{MHC} \mathrm{II}^{+} / \mathrm{CD} 11 \mathrm{c}^{+} / \mathrm{CD} 123^{-}$ (IL-3R $\alpha) / \mathrm{BDCA}^{+}{ }^{+}$, pDC are Lin-/MHC $\mathrm{II}^{+} / \mathrm{CD} 11 \mathrm{c}^{-} / \mathrm{CD} 123^{+} / \mathrm{BDCA}-2^{+}$and Ig-like transcript $7^{+}$. In mice, $\mathrm{mDC}$ are $\mathrm{CD} 11 \mathrm{c}^{+} \mathrm{CD} 11 \mathrm{~b}^{+} \mathrm{NK} 1.1^{-}$, whereas $\mathrm{pDC}$ are $\mathrm{B} 220^{+} \mathrm{CD} 11 \mathrm{c}^{\mathrm{lo}} \mathrm{CD} 11 \mathrm{~b}^{-} \mathrm{Gr}-1^{+}$and express the murine pDC Ag-1/BM stromal cell Ag (BST)-2/CD317. Other mouse pDC markers include Siglec-H and the chemokine receptor CCR9. Based on their phenotypic and functional characteristics, DC can be identified at various stages of maturation, from immature through so-called 'semi-mature' to mature. Immature DC express high endo-and phagocytic capacity, low levels of MHC class II and co-stimulatory molecules (CD40, CD80 and CD86), and low T cell stimulatory ability. These cells are associated with induction of T cell anergy and generation of Treg. By contrast, mature DC that express high levels of MHC class II, CD80 and CD86, have strong migratory capacity, associated with upregulation of the lymphoid homing receptor CCR7. They secrete the Thelper (Th) 1 cell-driving cytokine IL-12. While in vitro, mature DC also expand Treg from naïve mice in the presence of IL-2, and increase their suppressive capacity [23] and ability to suppress autoimmunity [24], they also potently expand effector $\mathrm{T}$ cells.

Owing to their poor $\mathrm{T}$ cell stimulatory capacity, immature $\mathrm{mDC}$ have been considered the prototypic tolerogenic DC. The first reports to address the tolerogenic potential of immature DC $\left(\mathrm{CD} 205^{+}, \mathrm{MHC} \mathrm{II}^{+}, \mathrm{CD} 40^{\mathrm{dim}} \mathrm{CD} 80^{\mathrm{dim}}\right.$, and $\left.\mathrm{CD} 86^{\mathrm{dim}}\right)$ in experimental (murine cardiac) allograft survival were by Fu et al [25] and Lu L et al [26]. In these studies, immature donor $\mathrm{BM}$-derived $\mathrm{mDC}$ propagated in vitro in granulocyte-macrophage colony stimulating factor (GM-CSF) and administered 7 days before vascularized heart graft transplantation, significantly prolonged graft survival, either alone or in combination with co-stimulation blockade. Similar observations were reported by Lutz et al [27], who showed that immature $\mathrm{mDC}$, resistant to maturation, could prolong haplotype-specific heart allograft survival indefinitely ( $>100$ days) also when given 7 days before transplantation. Subsequently, evidence accumulated that various phenotypically diverse DC could also promote transplant tolerance. Thus, semi-mature, maturation-resistant, 'alternatively-activated' and geneticallymodified DC have all been shown to prolong allograft survival and promote tolerance, often in conjunction with costimulation blockade, lymphocyte-depleting Abs or conventional immunosuppression [3].

DC generated in vitro in the presence of tumor necrosis factor (TNF)- $\alpha$, IL-10 + transforming growth factor beta (TGF- $\beta$ ) or dexamethasone, display a "semi-mature" phenotype, with intermediate levels of MHC II, CD40, CD80, and CD86 expression. These DC can markedly prolong organ allograft survival and inhibit graft-versus-host disease (GVHD) following hematopoietic stem cell transplantation [28-30]. "Semi-mature" DC, modulated by vitamin D3 and dexamethasone, can express the inhibitory molecules immunoglobulin (Ig)-like transcript - 3 (ILT3) and the B7 family member programmed death ligand - 1 (PDL-1= B7-H1) that plays a role in the induction of Treg [31]. E-cadherin is an epithelial adhesion molecule that is also expressed by epidermal DC, i.e. Langerhans' cells (LC). Surface ligation of E-cadherin inhibits LC maturation [32], whereas disruption of E-cadherin-mediated cell-cell contact by DC induces a "mature" phenotype with tolerogenic capacity. Such "mature" DC are able to induce CD4 ${ }^{+} \mathrm{T}$ cells that produce IL-10 instead of IFN- $\gamma$, and provide protection against induction of experimental autoimmune encephalitis [33].

Apart from transplantation and autoimmunity, DC have been implicated in regulation of immune reactivity to the semi-allogeneic fetus. DC have been shown to be central to the control of immune tolerance at the maternal-decidual interface. In a study of the role of DC 
in maternal - fetal tolerance, bacterial lipopolysaccharide ( LPS) and IFN- $\alpha$ activation of human chorionic gonadotropin - treated, BM-derived and splenic DC, downregulated MHC II expression, but maintained high CD80 and CD86 expression, maintained high IL-12, but significantly increased IL-10 production [34], suggesting mechanisms by which these DC might regulate immune reactivity directed against the fetus.

Thus, while the correlation between DC maturation and functional characteristics is well recognized, these data highlight the complexity of the relationship between DC phenotype and their tolerogenic potential.

\section{Maintenance of central tolerance by tol DC}

DC are essential for the maintenance of both central and peripheral tolerance in the normal steady state, where depletion of all subsets DC (including pDC and LC) in mice results in fatal autoimmunity [35]. Central tolerance is achieved through negative selection of self- or foreign Ag-reactive thymocytes and is a highly-efficient process mediated by APC and the induction of Treg in the thymus. Circulating DC have been shown to migrate to the thymic medulla through a three-step adhesion cascade involving P-selectin, interactions of the integrin very late Ag 4 (VLA-4) with its ligand vascular cell adhesion molecule -1 (VCAM-1), and pertussis toxin-sensitive chemoattractant signaling [36]. Using a thymic transplantation system, Proietto et al [37] have demonstrated that DC in the periphery can migrate into the thymus, where they efficiently induce Treg generation and negative selection. In diabetes-prone, non-obese diabetic (NOD) mice, BM-derived DC treated with thymic stromal lymphopoietin (TSLP) produced by Hassall's corpuscles in the thymic medulla, acquire a tolerogenic phenotype, induce the conversion of naïve $\mathrm{T}$ cells into functional $\mathrm{CD} 4^{+} \mathrm{CD} 25^{+} \mathrm{Foxp} 3^{+}$Treg, and provide protection from autoimmune diabetes [38]. Similarly to thymic $\mathrm{mDC}$, thymic $\mathrm{pDC}$ can drive nTreg development and also induce Treg $[39,40]$. The Treg induced by pDC are more efficient producers of IL-10 than those induced by thymic $\mathrm{mDC}$. These data emphasize the role of DC in both the development and education of $\mathrm{T}$ cells in the thymus.

\section{Mechanisms that maintain peripheral tolerance by tol DC}

In the absence of inflammation, tol DC maintain peripheral tolerance to self Ags through various inter-related mechanisms, including $\mathrm{T}$ cell deletion, induction of $\mathrm{T}$ cell anergy and induction of Treg, expression of immunomodulatory molecules, and production of immunosuppressive factors (e.g. IL-10; TGF $\beta$; and indoleamine dioxygenase [IDO]). APC expressing IDO play a critical role in maintaining peripheral tolerance. Prolongation of pancreatic islet allograft survival in mice by soluble cytotoxic $\mathrm{T}$ lymphocyte-associated $\mathrm{Ag}$ 4 (CTLA4) fusion protein (CTLA4-Ig) requires intact tryptophan catabolism in the recipient, likely due to the ability of CTLA4-Ig to upregulate IDO production by host DC [41]. In the mouse spleen, an $\mathrm{IDO}^{+} \mathrm{CD} 19^{+} \mathrm{DC}$ subset exhibits a mature phenotype in the steady-state, and synthesizes high amounts of IDO that mediate T cell suppression. IDO ${ }^{+} \mathrm{CD} 19^{+} \mathrm{DC}$ increase their production of IDO following CD80/86 ligation by CTLA4 [42, 43] or TLR9 ligation [44], and require autocrine release of IFN- $\alpha$ for signal transducer and activator of $\mathrm{T}$ cells (STAT) 1 activation and IDO up-regulation. Inhibition of IDO expression by silencing RNA (siRNA) inhibits DC-mediated suppression of Tcell proliferation [45]. Tryptophandeprived DC show reduced capacity to stimulate T cells, express high ILT3 and LT4, and induce suppressive $\mathrm{CD} 4^{+} \mathrm{CD} 25^{+} \mathrm{Foxp} 3^{+}$Treg [46]. In rodents, $\mathrm{CD} 103^{+} \mathrm{DC}$ in mesenteric lymph nodes and intestinal mucosa have been shown to express IDO. Inhibition of IDO activity induces Th1 and Th17 T cells in vivo, and prevents the development of Treg specific for oral Ags [47]. In an autocrine manner, murine tolerogenic CD8 ${ }^{+} \mathrm{DC}$ secrete TGF- $\beta$ which maintains IDO activation [48]. In a mouse model of collagen-induced arthritis, 
LPS-stimulated DC upregulate IDO expression, induce markers for Treg (Foxp3, TGF- $\beta 1$ and CTLA-4) in vivo, and improve arthritis scores when injected after immunization [49].

The programmed death-1 (PD-1) receptor is an inhibitory molecule expressed on activated T cells and its ligands, PD-L1 and PD-L2, contribute to the negative regulation of T lymphocyte activation and peripheral tolerance. PD-1-PD-L1 interactions maintain peripheral tolerance by mechanisms distinct from those of CTLA-4. Ab-mediated blockade of PD-1 or PD-L1 results in enhanced T cell-DC interaction and autoimmune diabetes [50]. It has been reported that PD-L1 and PD-L2 are expressed at very low levels on immature LC. Mature epidermal LC lack PD-1 expression, but express high levels of PD-L1 and PDL2. Also, blockade of PD-L1 and/or PD-L2 on dermal DC results in enhanced T cell activation [51]. Thus, LC not only have tolerogenic properties, but also have regulatory functions that can counteract the pro-inflammatory activity of surrounding keratinocytes.

Heme oxygenase-1 (HO-1) is an intracellular enzyme that degrades heme and inhibits inflammation in vivo. Human DC dramatically decrease HO-1 expression during their maturation in vitro. By contrast, cobalt protoporphyrin induction of $\mathrm{HO}-1$ expression is associated with downregulation of LPS-induced human DC maturation, secretion of antiinflammatory cytokines, and inhibition of alloreactive T-cell proliferation. Also, induction of HO-1 inhibits the production of reactive oxygen species (ROS) induced by LPS in human DC, although their ability to produce IL-10 is maintained [52].

The non-classical MHC class I Ag HLA-G is expressed on human DC and T cells, and is involved in tolerance induction [53]. HLA-G is a key molecule in the regulation of alloimmune responses at the human fetal-maternal interface. It interacts with three inhibitory receptors: ILT2, ILT4, and killer cell Ig--like receptor 2DL4 (KIR2DL4). HLA-G modulates immune responses through protection from NK cell- and cytotoxic T-lymphocyte-mediated cytolysis, inhibition of allogeneic T-cell proliferation, and modulation of DC function. HLA-G/ILT4 interaction promotes the development of tol DC [54, 55].

During pregnancy, a population of immature decidual DC appears to differentially express specific intercellular adhesion molecule-3-grabbing non-integrin (DC-SIGN; a C-type lectin). Human DC-SIGN ${ }^{+}$cells are $\mathrm{CD} 83^{+} \mathrm{CD} 25^{+} \mathrm{mDC}$, with a high capacity to stimulate naive T-cell proliferation. DC-SIGN mDC appear during early pregnancy in the human endometrium and are closely associated with inter-cellular adhesion molecule -3 expressing large granular lymphocytes (LGL), which have been shown to produce high local concentrations of GM-CSF and IL-10. Due to the high affinity of DC-SIGN for ICAM-3, it has been suggested that interaction between these two cell populations (DC-SIGN ${ }^{+}$and LGL) may prevent the interaction of DC-SIGN ${ }^{+}$cells with $\mathrm{T}$ cells and further maturation of DC-SIGN into potent immunostimulatory DC [56].

\section{ToL DC and Treg induction}

Naturally-occurring Treg are thymic-derived $\mathrm{CD} 4^{+} \mathrm{CD} 25^{+} \mathrm{Foxp}^{+} \mathrm{T}$ cells that constitute a significant population (5-10\%) of peripheral T cells in normal mice. In humans, their incidence among $\mathrm{CD}^{+} \mathrm{T}$ cells declines with age, starting from a range of 4-10\% in cord blood, decreasing to $1-4 \%$ in young adults and to $0.5-1.5 \%$ in healthy elderly donors [57]. In addition to their role in T cell anergy and deletion, DC in the periphery are pivotal in Treg induction, where their ability to induce and interact with Treg is critical for their tolerogenic effect. Also, conversely, Treg can promote the tolerogenic phenotype and capacity of DC. $\mathrm{CD} 4^{+} \mathrm{CD} 25^{+}$Treg activated with anti-CD3 overexpress CTLA4 and can condition DC to express IDO functional activity. This effect requires B7 expression and IFN- $\gamma$ production by DC. Additionally, in the same study, $\mathrm{CD} 4{ }^{+} \mathrm{CD} 25^{+}$Treg activated with LPS could induce 
tryptophan catabolism in DC through a CTLA4-independent but cytokine-dependent mechanism [58].

DC regulate the suppressive ability, expansion and/or differentiation of Treg in vitro [59]. This dynamic interaction between DC and Treg has been confirmed in vivo, where loss of DC results in a loss of Treg, increases IFN- $\gamma$ - and IL-17-producing T cells, and is associated with increased risk of autoimmune disease [60]. A "feedback" regulatory loop has been proposed, where, under steady-state conditions, the decrease in Treg results in a fms-like tyrosine kinase-3 (Flt3)-dependent increase in DC, which leads to increased homeostatic expansion of Treg. Additionally, absence of CTLA4 on Treg reduces the frequency of DC expressing IDO in mesenteric lymph nodes. Moreover, mice genetically deficient in CCR4 (CCL22 receptor) on Treg show markedly reduced IDO expression by mesenteric lymph node DC [61].

IL-10 contributes to the induction of anergy and the development of suppressive $\mathrm{T}$ cells and plays a fundamental role in the reciprocal effects of tol DC and Treg. Costimulation of $\mathrm{CD}^{+} \mathrm{T}$ cells through the inducible costimulatory (ICOS) molecule results in IL-10 production. On the other hand, blocking of the ICOS/ICOS-L interaction abolishes anergy induction in human $\mathrm{CD}^{+} \mathrm{T}$ cells by immature DC. $\mathrm{CD} 4^{+} \mathrm{T}$ cells from ICOS-deficient patients are completely resistant to anergy induction and differentiation into suppressor $\mathrm{T}$ cells, even after supplementation of IL-10 [62]. Tol DC secreting high levels of IL-10 (DC10) in the absence of IL-12 induce adaptive IL-10-producing regulatory type-1 (Tr1) T cells [63].

Unlike $\mathrm{mDC}$, maturing $\mathrm{pDC}$ increase their expression of ICOS-L that is involved in de novo differentiation of IL-10-producing Treg [64]. Moreover, in mice, pDC can down-regulate T cell responses through upregulation of IDO, a phenomenon that requires engagement of CD200 or glucocorticoid-induced TNF receptor ligand on the APC and autocrine release of type-I IFNs $[65,66]$. Furthermore, human pDC matured by TLR9 ligation promote Treg differentiation [67], and when activated with IL-3 plus CD40 ligation, induce CD8 ${ }^{+}$Treg [68]. CD40 ligand stimulation of mature human $\mathrm{pDC}$ but not $\mathrm{mDC}$, primes naive $\mathrm{CD}^{+} \mathrm{T}$ cells to become IL-10-producing Treg [69]. In parallel, human $\mathrm{CD}^{+} \mathrm{CD} 28^{-} \mathrm{T}$ suppressor cells can also inhibit the function of $\mathrm{mDC}$ by increasing expression of the inhibitory receptors ILT3 and ITL4, that interfere with nuclear factor $-\kappa B$-mediated activation of the DC [70].

\section{Tol DC and memory T cells}

Heterogeneity in the memory cell population of the human immune system can lead to donor cross-reactive memory T cells in transplant recipients. High frequencies of Agexperienced memory $\mathrm{T}$ cells correlate with enhanced rejection risk and are a major hurdle to tolerance induction in humans. Human memory T cells are resistant to depletion (e.g. by Campath-1H) [71]. Also, there is growing evidence that effector memory T cells are relatively resistant to costimulation blockade. Tolerance induction protocols based on CTLA-4-Ig have been found to be ineffective in recipients that possess cross-reactive, viruselicited donor-reactive effector memory $\mathrm{T}$ cells. These recipients show lack of attenuation of donor-reactive $\mathrm{CD}^{+} \mathrm{T}$-cell responses [72]. Significantly, human 'alternatively-activated', monocyte-derived DC (moDC) (conditioned by exposure to vitamin (Vit) D3 and dexamethasone, then LPS-stimulated), induce anergy in allogeneic memory $\mathrm{CD}^{+} \mathrm{T}$ cells which is IL-10-independent [73]. The induction of anergy in these memory T cells can be prevented by exogenous IL-12p70, but not by depleting CD $4{ }^{+} \mathrm{CD} 25^{\text {hi }} \mathrm{T}$ cells. Moreover, the tol DC do not expand Foxp $3^{+} \mathrm{T}$ cells preferentially from memory $\mathrm{T}$ cells. Similarly, earlier studies showed that co-cultures of dexamethasone-conditioned human moDC and 
alloreactive $\mathrm{CD}^{+}$memory $\mathrm{T}$ cells rendered the $\mathrm{T}$ cells hyporesponsive to restimulation with mature DC. Memory $\mathrm{CD}^{+} \mathrm{T}$ cells are a potent barrier to transplant tolerance induction. Adoptive transfer of fully-differentiated, long-lived $\mathrm{CD} 8^{+}$memory $\mathrm{T}$ cells geneticallytargeted in vivo by steady-state DC, results in initial expansion, followed by partial deletion, where residual $\mathrm{T}$ cells are unresponsive to further antigenic stimulation [74]. TLRstimulated allogeneic $\mathrm{pDC}$ induce $\mathrm{CD} 8^{+}$Treg that inhibit memory $\mathrm{T}$ cell alloimmune responses, [75]. The important ability of DC to inhibit memory $\mathrm{T}$ cell responses underscores the potential of these cells to regulate alloimmune responses in vivo.

\section{Allorecognition by donor versus recipient $D C$ in organ transplantation}

DC present alloAg to T cells through the direct, indirect or 'semi-direct' pathways of allorecognition [76-79]. Following transplantation, donor DC migrate from the graft and present donor MHC molecules to allospecific T cells via the direct pathway. Recipient DC that have processed donor alloAg present allopeptides on self (recipient) MHC molecules to donor-reactive $\mathrm{T}$ cells through the indirect pathway. Through the semi-direct pathway, $\mathrm{T}$ cells recognize donor MHC molecules transferred, intact, from donor cells to the surface of recipient DC [80]. Also, DC can acquire MHC molecules or allopeptides from other cells by the transfer of vesicles, or fragments of plasma membrane,- a process known as cell 'nibbling' [81]. The direct pathway is considered the main mechanism that leads to acute graft rejection, which decreases in influence with time after transplantation. On the other hand, the indirect pathway becomes the main mechanism of allorecognition at later times after transplantation, and is strongly implicated in chronic rejection.

\section{Role of tol DC in experimental organ transplantation}

In vitro propagation of tolerogenic donor- or recipient-derived DC has been used extensively as an experimental approach to target the pathways of allorecognition, with the aim of prolonging transplant survival, while reducing dependency on immunosuppressive drugs. The development of techniques to propagate large numbers of tol DC in vitro has provided the basis for ascertaining the ability of these cells to downregulate both host-versus-graft and graft-versus-host immune responses mediated by $\mathrm{T}$ cells (in the context of hematopoietic stem cell transplantation). There have been numerous reports of indefinite murine allograft survival following infusion of either donor- or recipient-derived tol DC (reviewed in [3]), administered either alone or in combination with conventional immunosuppressive drugs, costimulation blockade or T cell-depleting agents (Figure 2).

\section{Donor-derived Tol DC}

Intravenous infusion (7 days before transplantation) of in vitro-generated donor immature $\mathrm{mDC}$ significantly prolongs the survival of murine vascularized (heart) or non-vascularized (pancreatic islet) allografts [25, 82]. When combined with CD40-CD154 blockade, anti-Tcell therapy or, by using 'maturation-resistant' $\mathrm{mDC}$, mouse cardiac allograft survival can be prolonged extensively or indefinitely, without affecting acute rejection of third-party transplants [26, 27]. Alternatively, administration of donor blood monocyte-derived immature DC ( $\left.\mathrm{MHC} \mathrm{II}{ }^{+}, \mathrm{CD} 80^{\text {low }}, \mathrm{CD} 86^{-}\right)$, together with post-transplant total lymphoid irradiation and anti-thymocyte globulin, prolongs rat heart allograft survival indefinitely [83].

The role of $\mathrm{pDC}$ in experimental transplant tolerance has recently been examined. Intravenous administration of donor mouse pre-pDC before transplantation prolongs the survival of vascularized cardiac allografts significantly [84]. This effect was not found to be $\mathrm{Ag}$-specific however, as third-party $\mathrm{BM}$-derived $\mathrm{pDC}$ also significantly prolonged transplant survival, suggesting a non-specific immunosuppressive effect. Flt3L-mobilized donor 
splenic pDC also significantly prolong cardiac allograft survival in the absence of immunosuppression, an effect that is enhanced by combination with anti-CD154 mAb therapy [85]. In mice, pDC precursors (pre-pDC) facilitate allogeneic haematopoietic stem cell engraftment and promote tolerance to skin allografts [86].

A recent study in mice compared the thymus-homing capacity and tolerogenic function of in vitro-propagated allogeneic BM-derived $\mathrm{mDC}$ and $\mathrm{pDC}$. Only Flt3L-induced DC (containing both $\mathrm{mDC}$ and $\mathrm{pDC}$ ) and not GM-CSF-propagated $\mathrm{mDC}$ migrated to the recipient thymus after intravenous injection, and induced negative selection of donorreactive CD4 and CD8 single positive thymocytes. Notably, central and peripheral tolerance induced by Flt3L-mobilized donor DC infusion led to prolonged donor-specific skin allograft survival [87].

Donor DC may also impact the indirect pathway by "transporting" alloAg to recipient DC in host secondary lymphoid organs. Following subcutaneous footpad injection of BALB/cderived $\mathrm{DC}\left(\mathrm{IA}^{\mathrm{d}}, \mathrm{IE}^{+}\right)$into C57BL/6 recipient $\left(\mathrm{IA}^{\mathrm{b}}, \mathrm{IE}^{-}\right)$mice, host $\mathrm{DC}$ in the draining lymph nodes express the $\mathrm{IA}^{\mathrm{b}}-\mathrm{IE}_{\alpha 52-68}$ MHC-peptide complex [88]. In a recent study, maturation-resistant donor-derived DC were injected systemically and shown to be processed and donor Ag presented to recipient $\mathrm{T}$ cells by $\mathrm{CD} 11 \mathrm{c}$ hi host $\mathrm{DC}$. The injected donor DC were successful in prolonging cardiac allograft survival through delivery of donor $\mathrm{Ag}$ to recipient APC [89]. These donor-derived DC may not act directly through presentation of donor Ag. Rather that may serve as a source of donor Ag for recipient DC for presentation to indirect pathway $\mathrm{T}$ cells, down-regulation of the anti-donor response, and prolongation of allograft survival, similar to donor-specific transfusion. These conclusions raise important points regarding the underlying tolerogenic mechanisms of both donor versus recipient-derived DC. In the context of human organ transplantation, induction of donor-specific tolerance using donor-derived DC would require precise assessment of appropriate associated immunosuppressive therapy.

Most experimental protocols that have used donor-derived DC to prolong organ allograft survival require preparation of the DC several days before transplantation, which is applicable to live-donor renal and liver transplantation, but not to organ transplantation from deceased donors. Once injected, these donor-derived DCs may be eliminated by host natural killer (NK) cells, as shown in mice [90]. The importance of reprocessing donor alloAg by host DC following administration of DC is yet to be clarified and has significant therapeutic implications for the use of donor versus recipient DC to improve the outcome of clinical organ transplantation (see below). Administration of recipient-derived (autologous) tol DC loaded with donor alloAg be more advantageous, since these DC can be generated in vitro at any time, have an inherent potential to regulate the indirect pathway and thus potentially impact the development of chronic rejection, and may be associated with less risk of host sensitization.

\section{Recipient-derived Tol DC}

Recipient-derived DC pulsed with donor cell-derived Ags, including allopeptides, have been used to down-regulate the anti-donor $\mathrm{T}$ cell response and promote transplant tolerance. Intrathymic inoculation of recipient $\mathrm{BM}$-derived $\mathrm{mDC}$ pulsed with a donor allopeptide, in combination with a single dose of anti-lymphocyte serum, one week before transplantation, induced donor-specific tolerance to heart and pancreatic islet allografts in rats [91, 92]. This approach is potentially relevant to pediatric heart transplantation, where the young thymus is accessible during transplant surgery. By contrast, intravenously-injected $\mathrm{mDC}$ did not home to the thymus, but the presence of the thymus was critical for the induction of allograft 
tolerance. This contrasts to the aforementioned capability of donor-derived pDC and $\mathrm{mDC}$ (Flt3L-mobilized) to home to recipient thymus after their systemic injection.

We have reported that repetitive $(\times 2)$ intravenous administration of recipient-derived, maturation-resistant rapamycin-conditioned BM-derived $\mathrm{mDC}$, pulsed with cell-free lysate from donor splenocytes, prolongs cardiac allograft survival indefinitely in $40 \%$ of fully MHC-mismatched recipient mice [93]. Interestingly, the tolerogenic potential of non-pulsed, recipient-type immature BM-derived DC, administered the day before transplantation [94] to promote donor-specific tolerance, is potentiated by suboptimal immunosuppression with LF15-0195, a deoxyspergualin (DSG) analogue that inhibits DC maturation in vivo [95]. Recipient BM-derived mDC generated in vitro with GM-CSF, IL-10 and TGF $\beta 1$, and then stimulated with LPS ('alternatively-activated' DC, that produce IL-10 but little IL-12), prevent lethal GVHD following allogeneic BM transplantation in sublethally-irradiated mice [28]. By contrast, the tol DC do not restrain the ability of $\mathrm{CD}^{+} \mathrm{T}$ cells to mediate a graftversus-leukemia effect, indicating the immunomodulatory capacity of alternatively-activated $\mathrm{mDC}$ to selectively target $\mathrm{T}$ cell responses in vivo.

Since Ag presentation via the indirect pathway is thought to play a major role in the development of chronic rejection, activation of donor-specific $\mathrm{T}$ cells through the indirect pathway is considered a principal target for innovative tolerogenic therapies in organ transplantation. In a recent study [96], Ab-mediated targeting of recipient $\mathrm{mDC}$ in situ with intact MHC class I monomers inhibited the development of indirect alloresponses and the generation of IgG alloAbs by interfering with $\mathrm{T}$ cell-dependent $\mathrm{B}$ cell activation, resulting in MHC-mismatched skin allograft survival. This was achieved in combination with temporary inhibition of the direct alloimmune response using anti-CD8-depleting Ab.

It has been reported that host-derived pDC are integral to the development of vascularized organ allograft tolerance induced by DST and anti-CD154 mAb [97]. Thus, PDCA- ${ }^{+}$pDC acquired donor MHC II-derived allopeptide from the graft and migrated to LN (but not spleen), where they induced allo-specific $\mathrm{CD} 4^{+} \mathrm{Foxp} 3^{+}$Treg. In this model, pDC depletion or prevention of pDC LN homing inhibited Treg development and tolerance induction. However, in a rat model of cardiac allograft tolerance induced by CD40Ig, pDC accumulated in the graft and the spleen, but not $\mathrm{LN}$, and induced $\mathrm{CD} 8^{+}$Treg that suppressed $\mathrm{CD}^{+}$effector cells [98]. pDC regulation of alloreactive $\mathrm{CD} 4^{+} \mathrm{T}$ cells was either direct, through an IDO-dependent mechanism, or indirect through $\mathrm{CD}^{+}$Treg, in a contactdependent manner. Recently, it has been shown that complete absence of pDC within LN of $\mathrm{CCR}^{-1-}$ mice prevents the successful induction of tolerance to cardiac allografts (with DST and anti-CD154 mAb), whereas adoptive transfer of syngeneic pDC is sufficient to rescue graft survival in $\mathrm{CCR} 7^{-1-}$ recipients in a dose-dependent manner [99].

\section{Semi-allogeneic DC co-expressing recipient and donor MHC molecules}

Tol DC bearing both self and donor MHC molecules have been generated from BM precursors of semi-allogeneic (donor $\times$ recipient) F1 rodents or by the fusion of DC of different MHC haplotypes. Negative vaccination of (Lewis) (LEW) rats with dexamethasone-treated, semi-allogeneic BM-derived immature DC (from LEW $\times$ AUG [August] F1 rats) led to the indefinite survival of AUG-derived kidney grafts in LEW rats. No transplant vasculopathy was detected when this treatment was combined with CTLA4-Ig and a short, postoperative course of calcineurin inhibition (cyclosporine A; CsA) [29]. The data suggest that, in this model, pre-treatment of graft recipients with semi-allogeneic DC leads to indirect pathway-mediated regulation by Treg, the activity of which is dependent on the presence of the donor MHC molecules. In mice, injection of $\mathrm{F}_{1}(\mathrm{BALB} / \mathrm{c} \times \mathrm{C} 57 \mathrm{BL} / 6)$ DC expressing transgenic viral IL-10 and CCR7 (to enhance homing capacity to secondary 
lymphoid tissue) 7 days before transplant, results in indefinite survival of $F_{1}$ heart grafts in $>80 \%$ of C57BL/6 recipients [100].

Donor-recipient DC-DC hybrids have been created in vitro by fusing a CD95L (FasL)transduced DC line with allogeneic splenic DC, with the goal of inducing selective apoptosis of donor-reactive $\mathrm{T}$ cells that recognize alloAg though each possible pathway of allorecognition [101]. These CD95L-transduced DC-DC hybrids suppressed allospecific DTH responses against both parental strains, but did not affect responses to third party Ag. Repetitive intravenous administration resulted in delayed onset of GVHD in mice, due to MHC-restricted, CD95L-mediated apoptosis of donor anti-host CTL.

\section{Evidence of immune regulation by DC in humans and in clinical organ transplantation}

In humans, repetitive stimulation with monocyte-derived immature $\mathrm{mDC}$ pulsed with an HLA-A2-derived allopeptide has been used to expand alloAg-specific Treg ex vivo [102]. $\mathrm{mDC}$ can also down-regulate $\mathrm{CD} 8^{+} \mathrm{T}$ cell responses. Proof of principle that human immature DC can exhibit tolerogenic properties in vivo has been provided by studies of human volunteer responses to model Ags. Thus, in humans, subcutaneous injection of autologous, monocyte-derived immature DC pulsed with an influenza matrix peptide induced $\mathrm{Ag}$-specific regulatory $\mathrm{CD} 8^{+} \mathrm{T}$ cells secreting IL-10, and memory $\mathrm{CD} 8^{+} \mathrm{T}$ cells with impaired IFN- $\gamma$ secretion and cytolytic function [21, 22].

Analysis of peripheral blood DC in organ or BM transplant patients may be a helpful immune monitoring tool [103, 104]; reviewed in ref [6]. Higher incidences of circulating $\mathrm{pDC}$ relative to $\mathrm{mDC}$ are found in operationally tolerant pediatric liver allograft recipients and in patients on low dose immunosuppressive drug therapy undergoing prospective drug weaning, compared with patients on maintenance immunosuppression. These differences cannot be ascribed to the dose of immunosuppression or to the whole blood level of calcineurin inhibitor. In addition, high PD-L1/CD86 ratios on pDC correlate with elevated $\mathrm{CD} 4{ }^{+} \mathrm{CD} 25^{\text {hi }} \mathrm{Foxp}^{+}$Treg in transplant patients who exhibit a state of operational tolerance [105], which is consistent with evidence that the balance between expression of inhibitory PD-L1 and costimulatory CD80/CD86 ligands regulates the outcome of their interaction with T cells [106]. Patients treated with B7-CD28 costimulatory pathway blocking agent Lea29Y (Belatacept) display significantly higher soluble HLA-G (sHLA-G) plasma concentrations than patients treated with calcineurin inhibitors or healthy donors. In these investigations, DC were identified as one of the cellular sources of sHLA-G in the CTLA4Ig-treated patients [107]. As indicated above, interaction of HLA-G with its receptor ILT-4 on DC down-regulates their T-cell stimulatory capacity. In stable liver transplant patients off all immunosuppression, circulating mDC (but not pDC) express higher cell surface HLA-G, which correlates significantly with that of Foxp3 on Treg [108].

\section{Therapeutic tol DC: relevance to clinical organ transplantation}

The large amount of information generated from many pre-clinical rodent studies and in vitro work with human DC provides the basis for the development of a protocol for utilizing therapeutic DC in a clinical setting with special relevance to organ transplantation. It is clear that human DC can regulate immune reactivity by a variety of mechanisms, e.g. induction and expansion of Treg (such as $\mathrm{CD} 4^{+} \mathrm{CD} 25^{+} \mathrm{T}$ cells or $\mathrm{Tr} 1$ cells that make IL-10), anergy and/or deletion. Initial studies have demonstrated the feasibility of pharmacologic or genetic approaches to enhance and maintain the tolerogenicity of either ex vivo-generated donor or recipient DC. In transplantation, one of the potential concerns relating to the administration of tol DC is that, in the context of endogenous and exogenous danger signals, and in the 
presence of pro-inflammatory cytokines, the administered DC may mature and lose their immunomodulatory potential, or even accelerate graft rejection. This would be minimized/ avoided if DC were to be administered sufficiently in advance of transplantation (an approach adopted in most experimental small animal models). Such an approach is possible in live donor transplantation. In the deceased donor setting, adequate control of DC maturation would be essential. Notably, in rodents, maturation-resistant host DC administered post-transplant under cover of low dose immunosuppression can promote indefinite allograft survival [109], demonstrating their efficacy under these conditions.

Multiple pharmacologic and biologic agents, including anti-inflammatory and immunosuppressive drugs, as well as irradiation techniques have been evaluated for their potential to induce human tolerogenic DC (Table 1). These studies have evaluated phenotypic characteristics, cytokine production and $\mathrm{T}$ cell immunostimulatory capacity of the manipulated DC. The DC were either tested directly in vitro with or without the agent, or obtained from transplant patients already receiving the agent [110-115], in which case the DC were differentiated from isolated cells (blood monocytes) and evaluated for maturation and functional capacity.

Extracorporeal photopheresis (ECP) has been shown to be an effective treatment for, solid organ graft rejection, GVHD and other T cell-mediated diseases. ECP is an immunomodulatory therapy in which leukocytes are exposed to 8-methoxypsoralen (8MOP) and ultraviolet A radiation (PUVA). PUVA-treated or -untreated, highly-purified $\mathrm{CD} 14^{+}$cells (monocytes) were incubated with immunosuppressive drugs in the presence of IL-4 and GM-CSF. Neither immunosuppressive drugs at the lowest clinical concentration, nor their combination with PUVA, affected myeloid DC generation; however, a tolerogenic phenotype was induced. This approach may be useful for the generation of immature tol DC in vitro.

\section{Critical factors related to clinical DC therapy}

A number of logistic issues need to be evaluated prior to implementation of therapeutic human tol DC (Figure 3). For example, cell isolation and culture techniques for ex vivo preparation of tol DC can vary from one center to another, which can result in significant variation in cell yield. Use of Ficoll isolation and cryopreservation can result in a higher $\mathrm{pDC} / \mathrm{mDC}$ ratio than with fresh cells [116]. Also, it has been shown that initial culture of human DC can be associated with variability in surface molecule expression as well as cytokine production [117]. Additionally, materials used for clinical scale production of human DC in a "closed-system" have been shown to affect cytokine production by DC, e.g. IL-10 and IL-12, which might affect their therapeutic potential in vivo after administration [118]. This warrants technical standardization of DC preparation for clinical use.

In small animal models, BM or blood monocytes have been used successfully to generate tol DC that significantly prolong allograft survival. In humans, blood monocytes are the most common source for tol DC, in addition to other sources, e.g. cord blood or leukopheresis products. When recipient tol DC are considered, alloAg presentation by these cells requires targeting the DC with donor Ag. In rodents, several methods have been described for pulsing tol DC with donor Ag with successful therapeutic outcomes. These include cell-free lysate, MHC peptides, early apoptotic cells, or exosomes. The optimal approach for human in vivo use has not been determined.

The optimal route of administration of tol DC can be a critical step in tolerance induction, taking into consideration the desired migration of the injected tolDC to T cell areas in secondary lymphoid tissues. In a clinical trial of DC for cancer therapy, it was verified that radiolabeled DC injected intradermally had a higher migration rate to lymph nodes than DC 
injected subcutaneously. Also, mature DC showed greater migratory activity than immature DC [119]. In these studies, DC were detected in lymph nodes 20-60 min after injection, and the maximum concentration was reached after $48-72 \mathrm{~h}$. Although the purpose of this study was to induce immunostimulatory (rather than tolerogenic) effects, the observations highlight the possible effect of phenotypic maturation on the migratory capacity of the injected DC. Additional issues regarding DC administration are timing, dose and frequency. In a non-human primate model, a single intravenous infusion of donor-derived tol DC (VitaminD3/IL-10-treated to induce maturation resistance) together with a single CTLA4-Ig dose, resulted in modulation of allogeneic $\mathrm{T}$ cell responses and induction of hyporesponsiveness to donor and third party alloAgs [120].

Optimum immunosuppressive agents for combination therapy with tol DC need to be determined (Table 1). The immunosuppressive regimen administered to patients following transplantation may critically affect the therapeutic potential of tol DC. For example, a 4-day course of corticosteroids in healthy humans induces a fall in $\mathrm{pDC}$ numbers that begin to recover immediately after steroid withdrawal [121]. Mammalian target of rapamycin inhibitors such as rapamycin and calcineurin inhibitors can have differential effects on DC subsets in the circulation after transplantation [122]. T cell-depleting agents can also deplete DC. Thus Campath-1H (anti-CD52) mAb caused a strong, sustained reduction in the total number of peripheral $\mathrm{DC}$, with a significant shift in the $\mathrm{pDC} / \mathrm{mDC}$ ratio towards $\mathrm{pDC}$ as early as one month following kidney transplantation [123]. Other issues include stable DC immaturity/tolerogenicity/specificity, ensuring minimal risk of host sensitization; outcomes that can be monitored adequately in the laboratory and clinic; overcoming heterologous immunity/memory/late graft failure; regulatory issues: safety (GMP compliance); standardization/quality control; commercialization of therapeutic product.

\section{Pre-clinical studies in non-human primates (NHP)}

As yet, there are no reports of tol DC therapy in NHP organ transplantation. While small animal models provide important insight into mechanisms underlying tolerance induction, translation into the clinical setting has proven to be much more difficult, possibly due to differences between rodent and human leukocyte biology, and the barrier of heterologous immunity/T cell memory that is more prevalent in humans. Pre-clinical studies in NHP can provide a great amount of information that is needed to establish tol DC in relation to cell and organ transplantation. NHP models (especially rhesus macaques) have proven valuable tools in immunological studies utilizing DC therapy to mount an immune response to control infection and cancer, i.e. as a vaccine therapy. From a different perspective, tol DC can potentially be used to ameliorate the adaptive immune response to an allograft, i.e. negative vaccination. NHP tol DC have been characterized where vitD3/IL-10 treated (maturationresistant) tol DC were propagated and infused safely in rhesus macaques. . Systemic administration of these cells, in conjunction with CTLA4Ig, was well-tolerated and associated with significant hyporesponsiveness to donor allo-Ags [124]. Additionally, coculturing these cells with $\mathrm{CD} 4^{+} \mathrm{CD} 127^{-/ \mathrm{lo}} \mathrm{T}$ cells resulted in the generation of anergic $\mathrm{T}$ cells with allo-Ag specific suppressive capacity in vitro [120]. In a recent study, after culturing BM-derived rhesus macaque DC in vitro, adherent (but not non-adherent DC) were found to be poor stimulators of $\mathrm{T}$ cells and inhibited T-cell proliferation, i.e. tol DC, via a heme oxygenase-1 (HO-1)-dependent mechanism [125]. Further studies of tol DC in the NHP model are likely to provide important insights into strategies for potential clinical application (Figure 3). 


\section{Acknowledgments}

The authors' work is supported by National Institutes of Health grants R01 AI67541, U01 AI51698; U01 AI91197 and P01 AI81678.

\section{Abbreviations}

$\begin{array}{ll}\text { APC } & \text { antigen-presenting cell } \\ \text { BM } & \text { bone marrow } \\ \text { mDC } & \text { myeloid dendritic cell } \\ \text { pDC } & \text { plasmacytoid dendritic cell } \\ \text { Treg } & \text { regulatory T cell } \\ \text { tol DC } & \text { tolerogenic dendritic cell }\end{array}$

\section{REFERENCES}

[1]. Anderson G, Moore NC, Owen JJ, Jenkinson EJ. Cellular interactions in thymocyte development. Annu Rev Immunol. 1996; 14:73-99. [PubMed: 8717508]

[2]. Matzinger P, Guerder S. Does T-cell tolerance require a dedicated antigen-presenting cell? Nature. 1989; 338:74-76. [PubMed: 2783992]

[3]. Morelli AE, Thomson AW. Tolerogenic dendritic cells and the quest for transplant tolerance. Nat Rev Immunol. 2007; 7:610-621. [PubMed: 17627284]

[4]. Steinman RM. The dendritic cell system and its role in immunogenicity. Annu Rev Immunol. 1991; 9:271-296. [PubMed: 1910679]

[5]. Lechler RI, Ng WF, Steinman RM. Dendritic cells in transplantation - friend or foe? Immunity. 2001; 14:357-368. [PubMed: 11336681]

[6]. Solari MG, Thomson AW. Human dendritic cells and transplant outcome. Transplantation. 2008; 85:1513-1522. [PubMed: 18551047]

[7]. Matta BM, Castellaneta A, Thomson AW. Tolerogenic plasmacytoid DC. Eur J Immunol. 2010; 40:2667-2676. [PubMed: 20821731]

[8]. Maldonado RA, von Andrian UH. How tolerogenic dendritic cells induce regulatory T cells. Adv Immunol. 2010; 108:111-165. [PubMed: 21056730]

[9]. Pulendran B, Tang H, Manicassamy S. Programming dendritic cells to induce T(H)2 and tolerogenic responses. Nat Immunol. 2010; 11:647-655. [PubMed: 20644570]

[10]. Barratt-Boyes SM, Thomson AW. Dendritic cells: tools and targets for transplant tolerance. Am J Transplant. 2005; 5:2807-2813. [PubMed: 16302992]

[11]. van Kooten C, Lombardi G, K.A. G, Sagoo P, Buckland M, Lechler RI, et al. Dendritic cells as a tool to induce transplantation tolerance: obstacles and opportunities. Transplantation. 2011; 91:27. [PubMed: 21452405]

[12]. Hilkens CM, Isaacs JD, Thomson AW. Development of dendritic cell-based immunotherapy for autoimmunity. Int Rev Immunol. 2010; 29:156-183. [PubMed: 20199240]

[13]. Palucka AK, Ueno H, Fay J, Banchereau J. Dendritic cells: a critical player in cancer therapy? J Immunother. 2008; 31:793-805. [PubMed: 18833008]

[14]. Mittag D, Proietto AI, Loudovaris T, Mannering SI, Vremec D, Shortman K, et al. Human Dendritic Cell Subsets from Spleen and Blood Are Similar in Phenotype and Function but Modified by Donor Health Status. J Immunol. 2011

[15]. Shortman K, Liu YJ. Mouse and human dendritic cell subtypes. Nat Rev Immunol. 2002; 2:151161. [PubMed: 11913066]

[16]. Steinman RM, Cohn ZA. Identification of a novel cell type in peripheral lymphoid organs of mice. I. Morphology, quantitation, tissue distribution. J Exp Med. 1973; 137:1142-1162. [PubMed: 4573839] 
[17]. Steinman RM, Cohn ZA. Identification of a novel cell type in peripheral lymphoid organs of mice. II. Functional properties in vitro. J Exp Med. 1974; 139:380-397. [PubMed: 4589990]

[18]. Liu Y-J. IPC: Professional Type 1 interferon-producing cells and plasmacytoid dendritic cell precursors. Annu Rev Immunol. 2005; 23:275-306. [PubMed: 15771572]

[19]. Shortman K, Naik SH. Steady-state and inflammatory dendritic-cell development. Nat Rev Immunol. 2007; 7:19-30. [PubMed: 17170756]

[20]. Cisse B, Caton ML, Lehner M, Maeda T, Scheu S, Locksley R, et al. Transcription factor E2-2 is an essential and specific regulator of plasmacytoid dendritic cell development. Cell. 2008; 135:37-48. [PubMed: 18854153]

[21]. Dhodapkar MV, Steinman RM. Antigen-bearing immature dendritic cells induce peptide-specific CD8(+) regulatory T cells in vivo in humans. Blood. 2002; 100:174-177. [PubMed: 12070024]

[22]. Dhodapkar MV, Steinman RM, Krasovsky J, Munz C, Bhardwaj N. Antigen-specific inhibition of effector T cell function in humans after injection of immature dendritic cells. J Exp Med. 2001; 193:233-238. [PubMed: 11208863]

[23]. Yamazaki S, Patel M, Harper A, Bonito A, Fukuyama H, Pack M, et al. Effective expansion of alloantigen-specific Foxp3+ CD25+CD4+ regulatory T cells by dendritic cells during the mixed leukocyte reaction. Proc Natl Acad Sci U S A. 2006; 103:2758-2763. [PubMed: 16473944]

[24]. Tarbell KV, Yamazaki S, Olson K, Toy P, Steinman RM. CD25+ CD4+ T cells, expanded with dendritic cells presenting a single autoantigenic peptide, suppress autoimmune diabetes. J Exp Med. 2004; 199:1467-1477. [PubMed: 15184500]

[25]. Fu F, Li Y, Qian S, Lu L, Chambers F, Starzl TE, et al. Costimulatory molecule-deficient dendritic cell progenitors (MHC class $\mathrm{II}^{+}, \mathrm{CD} 80^{\mathrm{dim}}, \mathrm{CD}^{-}{ }^{-}$) prolong cardiac allograft survival in nonimmunosuppressed recipients. Transplantation. 1996; 62:659-665. [PubMed: 8830833]

[26]. Lu L, Li W, Fu F, Chambers FG, Qian S, Fung JJ, et al. Blockade of the CD40-CD40 ligand pathway potentiates the capacity of donor-derived dendritic cell progenitors to induce long-term cardiac allograft survival. Transplantation. 1997; 64:1808-1815. [PubMed: 9422424]

[27]. Lutz MB, Suri RM, Niimi M, Ogilvie AL, Kukutsch NA, Rossner S, et al. Immature dendritic cells generated with low doses of GM-CSF in the absence of IL-4 are maturation resistant and prolong allograft survival in vivo. Eur J Immunol. 2000; 30:1813-1822. [PubMed: 10940870]

[28]. Sato K, Yamashita N, Yamashita N, Baba M, Matsuyama T. Regulatory dendritic cells protect mice from murine acute graft-versus-host disease and leukemia relapse. Immunity. 2003; 18:367-379. [PubMed: 12648454]

[29]. Mirenda V, Berton I, Read J, Cook T, Smith J, Dorling A, et al. Modified dendritic cells coexpressing self and allogeneic major histocompatibility complex molecules: an efficient way to induce indirect pathway regulation. J Am Soc Nephrol. 2004; 15:987-997. [PubMed: 15034101]

[30]. Lan A, Wang Z, Raimondi G, Wu W, Colvin BL, DeCreus A, et al. `Alternatively-activated' dendritic cells preferentially secrete IL-10, expand Foxp $3^{+} \mathrm{CD} 4^{+} \mathrm{T}$ cells and induce long-term organ allograft survival in combination with CTLA4-Ig. J Immunol. 2006; 177:5868-5877. [PubMed: 17056511]

[31]. Unger WW, Laban S, Kleijwegt FS, van der Slik AR, Roep BO. Induction of Treg by monocytederived DC modulated by vitamin D3 or dexamethasone: differential role for PD-L1. Eur J Immunol. 2009; 39:3147-3159. [PubMed: 19688742]

[32]. Riedl E, Stockl J, Majdic O, Scheinecker C, Knapp W, Strobl H. Ligation of E-cadherin on in vitro-generated immature Langerhans-type dendritic cells inhibits their maturation. Blood. 2000; 96:4276-4284. [PubMed: 11110702]

[33]. Jiang A, Bloom O, Ono S, Cui W, Unternaehrer J, Jiang S, et al. Disruption of E-cadherinmediated adhesion induces a functionally distinct pathway of dendritic cell maturation. Immunity. 2007; 27:610-624. [PubMed: 17936032]

[34]. Wan H, Versnel MA, Leijten LM, van Helden-Meeuwsen CG, Fekkes D, Leenen PJ, et al. Chorionic gonadotropin induces dendritic cells to express a tolerogenic phenotype. J Leukoc Biol. 2008; 83:894-901. [PubMed: 18171698]

[35]. Ohnmacht C, Pullner A, King SB, Drexler I, Meier S, Brocker T, et al. Constitutive ablation of dendritic cells breaks self-tolerance of CD4 T cells and results in spontaneous fatal autoimmunity. J Exp Med. 2009; 206:549-559. [PubMed: 19237601] 
[36]. Bonasio R, Scimone ML, Schaerli P, Grabie N, Lichtman AH, von Andrian UH. Clonal deletion of thymocytes by circulating dendritic cells homing to the thymus. Nat Immunol. 2006; 7:10921100. [PubMed: 16951687]

[37]. Proietto AI, van Dommelen S, Zhou P, Rizzitelli A, D'Amico A, Steptoe RJ, et al. Dendritic cells in the thymus contribute to T-regulatory cell induction. Proc Natl Acad Sci U S A. 2008; 105:19869-19874. [PubMed: 19073916]

[38]. Besin G, Gaudreau S, Menard M, Guindi C, Dupuis G, Amrani A. Thymic stromal lymphopoietin and thymic stromal lymphopoietin-conditioned dendritic cells induce regulatory T-cell differentiation and protection of NOD mice against diabetes. Diabetes. 2008; 57:21072117. [PubMed: 18477807]

[39]. Martin-Gayo E, Sierra-Filardi E, Corbi AL, Toribio ML. Plasmacytoid dendritic cells resident in human thymus drive natural Treg cell development. Blood. 2010; 115:5366-5375. [PubMed: 20357241]

[40]. Hanabuchi S, Ito T, Park WR, Watanabe N, Shaw JL, Roman E, et al. Thymic stromal lymphopoietin-activated plasmacytoid dendritic cells induce the generation of FOXP3+ regulatory T cells in human thymus. J Immunol. 2010; 184:2999-3007. [PubMed: 20173030]

[41]. Grohmann U, Orabona C, Fallarino F, Vacca C, Calcinaro F, Falorni A, et al. CTLA-4-Ig regulates tryptophan catabolism in vivo. Nat Immunol. 2002; 3:1097-1101. [PubMed: 12368911]

[42]. Baban B, Hansen AM, Chandler PR, Manlapat A, Bingaman A, Kahler DJ, et al. A minor population of splenic dendritic cells expressing CD19 mediates IDO-dependent T cell suppression via type I IFN signaling following B7 ligation. Int Immunol. 2005; 17:909-919. [PubMed: 15967784]

[43]. Mellor AL, Chandler P, Baban B, Hansen AM, Marshall B, Pihkala J, et al. Specific subsets of murine dendritic cells acquire potent $\mathrm{T}$ cell regulatory functions following CTLA4-mediated induction of indoleamine 2,3 dioxygenase. Int Immunol. 2004; 16:1391-1401. [PubMed: 15351783]

[44]. Mellor AL, Baban B, Chandler PR, Manlapat A, Kahler DJ, Munn DH. Cutting edge: CpG oligonucleotides induce splenic CD19+ dendritic cells to acquire potent indoleamine 2,3dioxygenase-dependent T cell regulatory functions via IFN Type 1 signaling. J Immunol. 2005; 175:5601-5605. [PubMed: 16237046]

[45]. Flatekval GF, Sioud M. Modulation of dendritic cell maturation and function with mono- and bifunctional small interfering RNAs targeting indoleamine 2,3-dioxygenase. Immunology. 2009; 128:e837-848. [PubMed: 19740345]

[46]. Brenk M, Scheler M, Koch S, Neumann J, Takikawa O, Hacker G, et al. Tryptophan deprivation induces inhibitory receptors ILT3 and ILT4 on dendritic cells favoring the induction of human CD4+CD25+ Foxp3+ T regulatory cells. J Immunol. 2009; 183:145-154. [PubMed: 19535644]

[47]. Matteoli G, Mazzini E, Iliev ID, Mileti E, Fallarino F, Puccetti P, et al. Gut CD103+ dendritic cells express indoleamine 2,3-dioxygenase which influences $\mathrm{T}$ regulatory/T effector cell balance and oral tolerance induction. Gut. 2010; 59:595-604. [PubMed: 20427394]

[48]. Belladonna ML, Volpi C, Bianchi R, Vacca C, Orabona C, Pallotta MT, et al. Cutting edge: Autocrine TGF-beta sustains default tolerogenesis by IDO-competent dendritic cells. J Immunol. 2008; 181:5194-5198. [PubMed: 18832670]

[49]. Jaen O, Rulle S, Bessis N, Zago A, Boissier MC, Falgarone G. Dendritic cells modulated by innate immunity improve collagen-induced arthritis and induce regulatory $\mathrm{T}$ cells in vivo. Immunology. 2009; 126:35-44. [PubMed: 18754812]

[50]. Fife BT, Pauken KE, Eagar TN, Obu T, Wu J, Tang Q, et al. Interactions between PD-1 and PDL1 promote tolerance by blocking the TCR-induced stop signal. Nat Immunol. 2009; 10:11851192. [PubMed: 19783989]

[51]. Pena-Cruz V, McDonough SM, Diaz-Griffero F, Crum CP, Carrasco RD, Freeman GJ. PD-1 on immature and PD-1 ligands on migratory human Langerhans cells regulate antigen-presenting cell activity. J Invest Dermatol. 2010; 130:2222-2230. [PubMed: 20445553]

[52]. Chauveau C, Remy S, Royer PJ, Hill M, Tanguy-Royer S, Hubert FX, et al. Heme oxygenase-1 expression inhibits dendritic cell maturation and proinflammatory function but conserves IL-10 expression. Blood. 2005; 106:1694-1702. [PubMed: 15920011] 
[53]. Gregori S, Tomasoni D, Pacciani V, Scirpoli M, Battaglia M, Magnani CF, et al. Differentiation of type $1 \mathrm{~T}$ regulatory cells $(\operatorname{Tr} 1)$ by tolerogenic DC-10 requires the IL-10-dependent ILT4/HLAG pathway. Blood. 2010; 116:935-944. [PubMed: 20448110]

[54]. Liang S, Ristich V, Arase H, Dausset J, Carosella ED, Horuzsko A. Modulation of dendritic cell differentiation by HLA-G and ILT4 requires the IL-6--STAT3 signaling pathway. Proc Natl Acad Sci U S A. 2008; 105:8357-8362. [PubMed: 18550825]

[55]. Laskarin G, Kammerer U, Rukavina D, Thomson AW, Fernandez N, Blois SM. Antigenpresenting cells and materno-fetal tolerance: an emerging role for dendritic cells. Am J Reprod Immunol. 2007; 58:255-267. [PubMed: 17681042]

[56]. Jokhi PP, King A, Loke YW. Production of granulocyte-macrophage colony-stimulating factor by human trophoblast cells and by decidual large granular lymphocytes. Hum Reprod. 1994; 9:1660-1669. [PubMed: 7530725]

[57]. Takahata Y, Nomura A, Takada H, Ohga S, Furuno K, Hikino S, et al. CD25+CD4+ T cells in human cord blood: an immunoregulatory subset with naive phenotype and specific expression of forkhead box p3 (Foxp3) gene. Exp Hematol. 2004; 32:622-629. [PubMed: 15246158]

[58]. Fallarino F, Grohmann U, Hwang KW, Orabona C, Vacca C, Bianchi R, et al. Modulation of tryptophan catabolism by regulatory T cells. Nat Immunol. 2003; 4:1206-1212. [PubMed: 14578884]

[59]. Fehervari Z, Sakaguchi S. Control of Foxp3+CD25+CD4+ regulatory cell activation and function by dendritic cells. Int Immunol. 2004; 16:1769-1780. [PubMed: 15520045]

[60]. Darrasse-Jeze G, Deroubaix S, Mouquet H, Victora GD, Eisenreich T, Yao KH, et al. Feedback control of regulatory T cell homeostasis by dendritic cells in vivo. J Exp Med. 2009; 206:18531862. [PubMed: 19667061]

[61]. Onodera T, Jang MH, Guo Z, Yamasaki M, Hirata T, Bai Z, et al. Constitutive expression of IDO by dendritic cells of mesenteric lymph nodes: functional involvement of the CTLA-4/B7 and CCL22/CCR4 interactions. J Immunol. 2009; 183:5608-5614. [PubMed: 19843945]

[62]. Tuettenberg A, Huter E, Hubo M, Horn J, Knop J, Grimbacher B, et al. The role of ICOS in directing T cell responses: ICOS-dependent induction of T cell anergy by tolerogenic dendritic cells. J Immunol. 2009; 182:3349-3356. [PubMed: 19265111]

[63]. Levings MK, Gregori S, Tresoldi E, Cazzaniga S, Bonini C, Roncarolo MG. Differentiation of Tr1 cells by immature dendritic cells requires IL-10 but not CD25+CD4+ Tr cells. Blood. 2005; 105:1162-1169. [PubMed: 15479730]

[64]. Ito T, Yang M, Wang YH, Lande R, Gregorio J, Perng OA, et al. Plasmacytoid dendritic cells prime IL-10-producing T regulatory cells by inducible costimulator ligand. J Exp Med. 2007; 204:105-115. [PubMed: 17200410]

[65]. Fallarino F, Asselin-Paturel C, Vacca C, Bianchi R, Gizzi S, Fioretti MC, et al. Murine plasmacytoid dendritic cells initiate the immunosuppressive pathway of tryptophan catabolism in response to CD200 receptor engagement. J Immunol. 2004; 173:3748-3754. [PubMed: 15356121]

[66]. Grohmann U, Volpi C, Fallarino F, Bozza S, Bianchi R, Vacca C, et al. Reverse signaling through GITR ligand enables dexamethasone to activate IDO in allergy. Nat Med. 2007; 13:579586. [PubMed: 17417651]

[67]. Moseman EA, Liang X, Dawson AJ, Panoskaltsis-Mortari A, Krieg AM, Liu YJ, et al. Human plasmacytoid dendritic cells activated by $\mathrm{CpG}$ oligodeoxynucleotides induce the generation of $\mathrm{CD}^{+} \mathrm{CD} 25^{+}$regulatory T cells. J Immunol. 2004; 173:4433-4442. [PubMed: 15383574]

[68]. Gilliet M, Boonstra A, Paturel C, Antonenko S, Xu XL, Trinchieri G, et al. The development of murine plasmacytoid dendritic cell precursors is differentially regulated by FLT3-ligand and granulocyte/macrophage colony-stimulating factor. J Exp Med. 2002; 195:953-958. [PubMed: 11927638]

[69]. Manches O, Munn D, Fallahi A, Lifson J, Chaperot L, Plumas J, et al. HIV-activated human plasmacytoid DCs induce Tregs through an indoleamine 2,3-dioxygenase-dependent mechanism. J Clin Invest. 2008; 118:3431-3439. [PubMed: 18776940] 
[70]. Chang CC, Ciubotariu R, Manavalan JS, Yuan J, Colovai AI, Piazza F, et al. Tolerization of dendritic cells by $\mathrm{T}(\mathrm{S})$ cells: the crucial role of inhibitory receptors ILT3 and ILT4. Nat Immunol. 2002; 3:237-243. [PubMed: 11875462]

[71]. Pearl JP, Parris J, Hale DA, Hoffmann SC, Bernstein WB, McCoy KL, et al. Immunocompetent T-cells with a memory-like phenotype are the dominant cell type following antibody-mediated Tcell depletion. Am J Transplant. 2005; 5:465-474. [PubMed: 15707400]

[72]. Adams AB, Williams MA, Jones TR, Shirasugi N, Durham MM, Kaech SM, et al. Heterologous immunity provides a potent barrier to transplantation tolerance. J Clin Invest. 2003; 111:18871895. [PubMed: 12813024]

[73]. Anderson AE, Sayers BL, Haniffa MA, Swan DJ, Diboll J, Wang XN, et al. Differential regulation of naive and memory $\mathrm{CD} 4+\mathrm{T}$ cells by alternatively activated dendritic cells. J Leukoc Biol. 2008; 84:124-133. [PubMed: 18430785]

[74]. Kenna TJ, Thomas R, Steptoe RJ. Steady-state dendritic cells expressing cognate antigen terminate memory CD8+ T-cell responses. Blood. 2008; 111:2091-2100. [PubMed: 18003887]

[75]. Boor PP, Metselaar HJ, Jonge SD, Mancham S, van der Laan LJ, Kwekkeboom J. Human plasmacytoid dendritic cells induce CD8(+) LAG-3(+) Foxp3(+) CTLA-4(+) regulatory T cells that suppress allo-reactive memory T cells. Eur J Immunol. 2011

[76]. Gould DS, Auchincloss H Jr. Direct and indirect recognition: the role of MHC antigens in graft rejection. Immunol Today. 1999; 20:77-82. [PubMed: 10098326]

[77]. Benichou G, Valujskikh A, Heeger PS. Contributions of direct and indirect T cell alloreactivity during allograft rejection in mice. J Immunol. 1999; 162:352-358. [PubMed: 9886406]

[78]. Smyth LA, Afzali B, Tsang J, Lombardi G, Lechler RI. Intercellular transfer of MHC and immunological molecules: molecular mechanisms and biological significance. Am J Transplant. 2007; 7:1442-1449. [PubMed: 17511673]

[79]. Dolan BP, Gibbs KD Jr. Ostrand-Rosenberg S. Tumor-specific CD4+ T cells are activated by "cross-dressed" dendritic cells presenting peptide-MHC class II complexes acquired from cellbased cancer vaccines. J Immunol. 2006; 176:1447-1455. [PubMed: 16424172]

[80]. Herrera OB, Golshayan D, Tibbott R, Salcido Ochoa F, James MJ, Marelli-Berg FM, et al. A novel pathway of alloantigen presentation by dendritic cells. J Immunol. 2004; 173:4828-4837. [PubMed: 15470023]

[81]. Thery C, Duban L, Segura E, Veron P, Lantz O, Amigorena S. Indirect activation of naive CD4+ T cells by dendritic cell-derived exosomes. Nat Immunol. 2002; 3:1156-1162. [PubMed: 12426563]

[82]. Rastellini C, Lu L, Ricordi C, Starzl TE, Rao AS, Thomson AW. Granulocyte/macrophage colony-stimulating factor-stimulated hepatic dendritic cell progenitors prolong pancreatic islet allograft survival. Transplantation. 1995; 60:1366-1370. [PubMed: 8525540]

[83]. Hayamizu K, Huie P, Sibley RK, Strober S. Monocyte-derived dendritic cell precursors facilitate tolerance to heart allografts after total lymphoid irradiation. Transplantation. 1998; 66:12851291. [PubMed: 9846510]

[84]. Abe M, Wang Z, De Creus A, Thomson AW. Plasmacytoid dendritic cell precursors induce allogeneic $\mathrm{T}$ cell hyporesponsiveness and prolong heart graft survival. Am J Transplant. 2005; 5:1808-1819. [PubMed: 15996227]

[85]. Bjorck P, Coates PT, Wang Z, Duncan FJ, Thomson AW. Promotion of long-term heart allograft survival by combination of mobilized donor plasmacytoid dendritic cells and anti-CD154 monoclonal antibody. J Heart Lung Transplant. 2005; 24:1118-1120. [PubMed: 16102450]

[86]. Fugier-Vivier IJ, Rezzoug F, Huang Y, Graul-Layman AJ, Schanie CL, Xu H, et al. Plasmacytoid precursor dendritic cells facilitate allogeneic hematopoietic stem cell engraftment. J Exp Med. 2005; 201:373-383. [PubMed: 15699072]

[87]. Yamano T, Watanabe S, Hasegawa H, Suzuki T, Abe R, Tahara H, et al. Ex-vivo expanded DC induce donor-specific central and peripheral tolerance and prolong the acceptance of donor skin allografts. Blood. 2011 Epub ahead of print.

[88]. Inaba K, Turley S, Yamaide F, Iyoda T, Mahnke K, Inaba M, et al. Efficient presentation of phagocytosed cellular fragments on the major histocompatibility complex class II products of dendritic cells. J Exp Med. 1998; 188:2163-2173. [PubMed: 9841929] 
[89]. Divito SJ, Wang Z, Shufesky WJ, Liu Q, Tkacheva OA, Montecalvo A, et al. Endogenous dendritic cells mediate the effects of intravenously injected therapeutic immunosuppressive dendritic cells in transplantation. Blood. 2010; 116:2694-2705. [PubMed: 20576812]

[90]. Yu G, Xu X, Vu MD, Kilpatrick ED, Li XC. NK cells promote transplant tolerance by killing donor antigen-presenting cells. J Exp Med. 2006; 203:1851-1858. [PubMed: 16864660]

[91]. Garrovillo M, Ali A, Oluwole SF. Indirect allorecognition in acquired thymic tolerance: induction of donor-specific tolerance to rat cardiac allografts by allopeptide-pulsed host dendritic cells. Transplantation. 1999; 68:1827-1834. [PubMed: 10628758]

[92]. Ali A, Garrovillo M, Jin MX, Hardy MA, Oluwole SF. Major histocompatibility complex class I peptide-pulsed host dendritic cells induce antigen-specific acquired thymic tolerance to islet cells. Transplantation. 2000; 69:221-226. [PubMed: 10670630]

[93]. Taner T, Hackstein H, Wang Z, Morelli AE, Thomson AW. Rapamycin-treated, alloantigenpulsed host dendritic cells induce Ag-specific T cell regulation and prolong graft survival. Am J Transplant. 2005; 5:228-236. [PubMed: 15643982]

[94]. Peche H, Trinite B, Martinet B, Cuturi MC. Prolongation of heart allograft survival by immature dendritic cells generated from recipient type bone marrow progenitors. Am J Transplant. 2005; 5:255-267. [PubMed: 15643985]

[95]. Beriou G, Peche H, Guillonneau C, Merieau E, Cuturi MC. Donor-specific allograft tolerance by administration of recipient-derived immature dendritic cells and suboptimal immunosuppression. Transplantation. 2005; 79:969-972. [PubMed: 15849552]

[96]. Tanriver Y, Ratnasothy K, Bucy RP, Lombardi G, Lechler R. Targeting MHC class I monomers to dendritic cells inhibits the indirect pathway of allorecognition and the production of $\operatorname{IgG}$ alloantibodies leading to long-term allograft survival. J Immunol. 2010; 184:1757-1764. [PubMed: 20083658]

[97]. Ochando JC, Homma C, Yang Y, Hidalgo A, Garin A, Tacke F, et al. Alloantigen-presenting plasmacytoid dendritic cells mediate tolerance to vascularized grafts. Nat Immunol. 2006; 7:652662. [PubMed: 16633346]

[98]. Li XL, Menoret S, Bezie S, Caron L, Chabannes D, Hill M, et al. Mechanism and localization of CD8 regulatory T cells in a heart transplant model of tolerance. J Immunol. 2010; 185:823-833. [PubMed: 20543104]

[99]. Liu X, Mishra P, Yu S, Beckmann J, Wendland M, Kocks J, et al. Tolerance induction towards cardiac allografts under costimulation blockade is impaired in CCR7-deficient animals but can be restored by adoptive transfer of syngeneic plasmacytoid dendritic cells. Eur J Immunol. 2011; 41:611-623. [PubMed: 21341262]

[100]. Garrod KR, Chang CK, Liu FC, Brennan TV, Foster RD, Kang SM. Targeted lymphoid homing of dendritic cells is required for prolongation of allograft survival. J Immunol. 2006; 177:863868. [PubMed: 16818740]

[101]. Matsue H, Matsue K, Kusuhara M, Kumamoto T, Okumura K, Yagita H, et al. Immunosuppressive properties of CD95L-transduced "killer" hybrids created by fusing donorand recipient-derived dendritic cells. Blood. 2001; 98:3465-3472. [PubMed: 11719389]

[102]. Jiang S, Camara N, Lombardi G, Lechler RI. Induction of allopeptide-specific human CD4+CD25+ regulatory T cells ex vivo. Blood. 2003; 102:2180-2186. [PubMed: 12775574]

[103]. Mazariegos GV. Withdrawal of immunosuppression in liver transplantation: lessons learned from PTLD. Pediatr Transplant. 2004; 8:210-213. [PubMed: 15176955]

[104]. Mazariegos GV, Zahorchak AF, Reyes J, Chapman H, Zeevi A, Thomson AW. Dendritic cell subset ratio in tolerant, weaning and non-tolerant liver recipients is not affected by extent of immunosuppression. Am J Transplant. 2005; 5:314-322. [PubMed: 15643991]

[105]. Tokita D, Mazariegos GV, Zahorchak AF, Chien N, Abe M, Raimondi G, et al. High PD-L1/ CD86 ratio on plasmacytoid dendritic cells correlates with elevated T-regulatory cells in liver transplant tolerance. Transplantation. 2008; 85:369-377. [PubMed: 18301333]

[106]. Okazaki T, Honjo T. The PD-1-PD-L pathway in immunological tolerance. Trends Immunol. 2006; 27:195-201. [PubMed: 16500147] 
[107]. Bahri R, Naji A, Menier C, Charpentier B, Carosella ED, Rouas-Freiss N, et al. Dendritic cells secrete the immunosuppressive HLA-G molecule upon CTLA4-Ig treatment: implication in human renal transplant acceptance. J Immunol. 2009; 183:7054-7062. [PubMed: 19915057]

[108]. Castellaneta A, Mazariegos GV, Nayyar N, Zeevi A, Thomson AW. HLA-G Level on Monocytoid Dendritic Cells Correlates With Regulatory T-Cell Foxp3 Expression in Liver Transplant Tolerance. Transplantation. 2011; 91:1132-1140. [PubMed: 21423069]

[109]. Ikeguchi R, Sacks JM, Unadkat JV, Solari M, Horibe EK, Thomson AW, et al. Long-term survival of limb allografts induced by pharmacologically conditioned, donor alloantigen-pulsed dendritic cells without maintenance immunosuppression. Transplantation. 2008; 85:237-246. [PubMed: 18212629]

[110]. Haidinger M, Poglitsch M, Geyeregger R, Kasturi S, Zeyda M, Zlabinger GJ, et al. A versatile role of mammalian target of rapamycin in human dendritic cell function and differentiation. $\mathrm{J}$ Immunol. 2010; 185:3919-3931. [PubMed: 20805416]

[111]. Weichhart T, Haidinger M, Katholnig K, Kopecky C, Poglitsch M, Lassnig C, et al. Inhibition of mTOR blocks the anti-inflammatory effects of glucocorticoids in myeloid immune cells. Blood. 2011; 117:4273-4283. [PubMed: 21368289]

[112]. Klangsinsirikul P, Carter GI, Byrne JL, Hale G, Russell NH. Campath-1G causes rapid depletion of circulating host dendritic cells (DCs) before allogeneic transplantation but does not delay donor DC reconstitution. Blood. 2002; 99:2586-2591. [PubMed: 11895797]

[113]. Gupta A, Ashokkumar C, Ningappa M, Sun Q, Higgs BW, Snyder S, et al. Elevated myeloid: plasmacytoid dendritic cell ratio associates with early acute cellular rejection in pediatric small bowel transplantation. Transplantation. 2010; 89:55-60. [PubMed: 20061919]

[114]. Botturi K, Lacoeuille Y, Thomas P, Boniface S, Reynaud-Gaubert M, Magnan A. CTLA-4mediated regulatory phenotype of T-cells in tolerant lung recipients. Eur Respir J. 2008; 31:1167-1176. [PubMed: 18256061]

[115]. Daniel V, Naujokat C, Sadeghi M, Wiesel M, Hergesell O, Opelz G. Association of circulating interleukin (IL)-12- and IL-10-producing dendritic cells with time posttransplant, dose of immunosuppression, and plasma cytokines in renal-transplant recipients. Transplantation. 2005; 79:1498-1506. [PubMed: 15940038]

[116]. Gerrits JH, Athanassopoulos P, Vaessen LM, Klepper M, Weimar W, van Besouw NM. Peripheral blood manipulation significantly affects the result of dendritic cell monitoring. Transpl Immunol. 2007; 17:169-177. [PubMed: 17331843]

[117]. Tawab A, Fan Y, Read EJ, Kurlander RJ. Effect of ex vivo culture duration on phenotype and cytokine production by mature dendritic cells derived from peripheral blood monocytes. Transfusion (Paris). 2009; 49:536-547.

[118]. Kurlander RJ, Tawab A, Fan Y, Carter CS, Read EJ. A functional comparison of mature human dendritic cells prepared in fluorinated ethylene-propylene bags or polystyrene flasks. Transfusion (Paris). 2006; 46:1494-1504.

[119]. Ridolfi R, Riccobon A, Galassi R, Giorgetti G, Petrini M, Fiammenghi L, et al. Evaluation of in vivo labelled dendritic cell migration in cancer patients. J Transl Med. 2004; 2:27. [PubMed: 15285807]

[120]. Zahorchak AF, Raimondi G, Thomson AW. Rhesus monkey immature monocyte-derived dendritic cells generate alloantigen-specific regulatory T cells from circulating CD4+CD127-/lo T cells. Transplantation. 2009; 88:1057-1064. [PubMed: 19898200]

[121]. Shodell M, Shah K, Siegal FP. Circulating human plasmacytoid dendritic cells are highly sensitive to corticosteroid administration. Lupus. 2003; 12:222-230. [PubMed: 12708787]

[122]. Barten MJ, Garbade J, Bittner HB, Fiedler M, Dhein S, Thiery J, et al. Affects of immunosuppression on circulating dendritic cells: an adjunct to therapeutic drug monitoring after heart transplantation. Int Immunopharmacol. 2006; 6:2011-2017. [PubMed: 17161355]

[123]. Kirsch BM, Haidinger M, Zeyda M, Bohmig GA, Tombinsky J, Muhlbacher F, et al. Alemtuzumab (Campath-1H) induction therapy and dendritic cells: Impact on peripheral dendritic cell repertoire in renal allograft recipients. Transpl Immunol. 2006; 16:254-257. [PubMed: 17138063] 
[124]. Zahorchak AF, Kean LS, Tokita D, Turnquist HR, Abe M, Finke J, et al. Infusion of stably immature monocyte-derived dendritic cells plus CTLA4Ig modulates alloimmune reactivity in rhesus macaques. Transplantation. 2007; 84:196-206. [PubMed: 17667811]

[125]. Moreau A, Hill M, Thebault P, Deschamps JY, Chiffoleau E, Chauveau C, et al. Tolerogenic dendritic cells actively inhibit $\mathrm{T}$ cells through heme oxygenase- 1 in rodents and in nonhuman primates. FASEB J. 2009 Epub ahead of print. 


\section{Highlights}

- Tolerogenic dendritic cells (DC) promote both central and peripheral tolerance

- In rodents, donor or recipient-derived tolerogenic DC can promote long-term organ allograft survival

- Peripheral blood DC with tolerogenic features have been detected in liver transplant patients with operational tolerance

- Tolerogenic DC have been shown to promote antigen-specific T cell tolerance to model antigens in human volunteers

- Pre-clinical trials in non-human primates will guide testing of tolerogenic DC therapy in human organ transplantation 


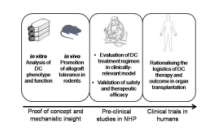

\section{Figure 1.}

Developmental stages of therapeutic tol DC in allotransplantation

Properties and phenotype of human and murine tol DC have been characterized in vitro and their potential to promote tolerance to organ allografts in vivo has been confirmed in rodents. Pre-clinical studies in a clinically relevant model (non-human primate) are required to evaluate tol DC as a therapeutic regimen and to validate its safety and efficacy. Clinical trials in humans will require assessment of various critical issues in relation to DC therapy and the outcome of organ allotransplantation. 


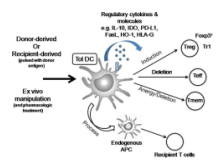

Figure 2.

Therapeutic tol-DC in organ allotransplantation

Tol DC can be either recipient- or donor-derived (in the case of living-donor transplantation). Recipient DC can be pulsed with donor antigen in various forms (donor cell lysate, exosomes, apoptotic bodies). During tol DC preparation, DC can be treated pharmacologically e.g. with dexamethasone VitD3/IL-10 to induce maturation resistance. Typical tol DC secrete and express cell surface regulatory molecules, that mediate the tolerogenic influence of tol DC on recipient T cells. As a result, tolerance to the donor antigen can be achieved through induction of regulatory $\mathrm{T}$ cells, as well as via the induction of anergy and deletion of effector and memory T cells. Additionally, infused tol DC can be reprocessed by recipient antigen-presenting cells (APC), promoting organ allograft survival through the indirect pathway. IDO, indoleamine dioxygenase; PD-L1, programed death ligand-1; HO-1, hemoxygenase-1. 


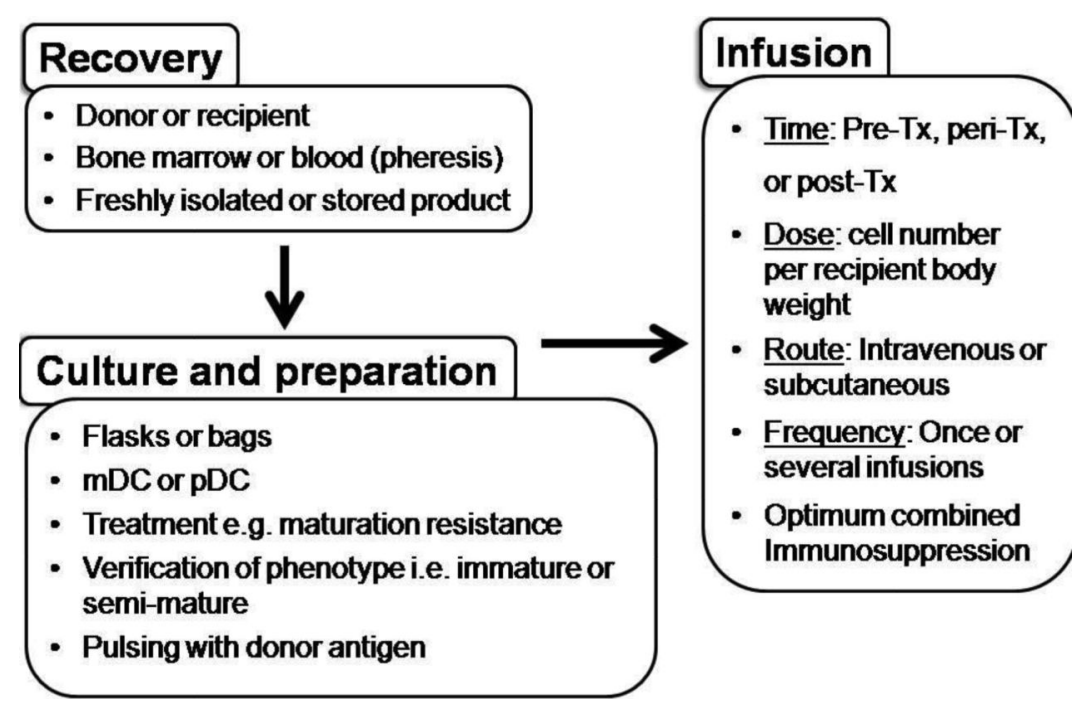

Figure 3.

Logistics of tol-DC therapy in organ allotransplantation

Evaluation of logistic issues will be needed for implementation of therapeutic tol DC. Prior to DC infusion, these include the source, recovery and purity of the DC, and preparation and pharmacologic treatment of tol DC. On tol DC infusion, additional logistics will be assessed. These include time and route of administration, and the frequency and dose of tol DC administered. Additionally, concomitant use of various immunosuppressive agents may have variable effects on DC viability, migration and function as is evident from studies of DC in human transplant patients (Table 1). 
Table 1

Results of DC analyses in relation to human transplant outcome including operational tolerance

\begin{tabular}{|c|c|c|c|}
\hline Transplant & Immunosuppression & DC profile $+/-T$ cell stimulatory capacity & Ref \\
\hline HSCT & Campath-1 & $\begin{array}{l}\text { - Reduction in the number of circulating DC by a mean of } 79 \%(44 \%- \\
96 \%) 24 \text { hours after one dose. } \\
\text { - } \quad \mathrm{CD} 11 \mathrm{c}^{(+)} \text {recovered more rapidly than } \mathrm{CD} 11 \mathrm{c}^{(-)}\end{array}$ & 112 \\
\hline Heart & $\begin{array}{l}\text { CsA or tacrolimus or } \\
\text { rapamycin then switch to } \\
\text { everolimus }\end{array}$ & $\begin{array}{l}\text { - } \mathrm{pDC} / \mathrm{mDC} \text { ratio was higher in patients receiving rapamycin compared } \\
\text { to patients receiving tacrolimus or CsA } \\
\text { - Patients receiving rapamycin, tacrolimus, or CsA displayed higher } \\
\text { IL-12 positive cells in the circulation } \\
\text { - Conversion to everolimus was associated with higher } \mathrm{pDC} / \mathrm{mDC} \text { ratio } \\
\text { and higher IL- } \beta \text { positive cells in the circulation }\end{array}$ & 122 \\
\hline Liver & $\begin{array}{l}\text { CsA or tacrolimus / } \\
\text { azathioprine / steroids }\end{array}$ & $\begin{array}{l}\text { - Tolerant patients exhibited significantly higher } \mathrm{pDC} 2 \mathrm{pDC} 1 \text { ratio than } \\
\text { control groups. } \\
\text { - } \quad \text { Neither tacrolimus nor prednisone affected the } \mathrm{pDC} 2 \text { :pDC1 ratio }\end{array}$ & 104 \\
\hline Liver & $\begin{array}{l}\text { tacrolimus / azathioprine / } \\
\text { steroids }\end{array}$ & $\begin{array}{l}\text { Tolerant patients have higher circulating } \mathrm{pDC} / \mathrm{mDC} \text { ratios where } \mathrm{pDC} \\
\text { exhibit significantly higher PD-L1/CD86 ratios. } \\
\text { - Significant correlation between surface PD-L1/CD86 ratio on } \mathrm{pDC} \text { and } \\
\mathrm{CD} 4^{+} \mathrm{CD} 25^{\text {hi }} \text { Treg frequency in tolerant patients } \\
\text { - No correlation observed between tacrolimus and prednisone dosage or } \\
\text { tacrolimus trough level and the PD-L1/CD86 ratio on circulating } \\
\text { precursor pDC, or the frequency of CD } 4^{+} \mathrm{CD} 25^{\text {hi }} \mathrm{T} \text { cells. }\end{array}$ & 105 \\
\hline Liver & $\begin{array}{l}\text { CsA or tacrolimus / } \\
\text { azathioprine / steroids }\end{array}$ & $\begin{array}{l}\text { - HLA-G expression was significantly higher on mDC (but not pDC) in } \\
\text { tolerant patients. } \\
\text { - Serum HLA-G levels were not significantly different between the } \\
\text { tolerant patients and other groups. } \\
\text { - Significant correlation between the intensity of HLA-G expression and } \\
\text { Foxp3 expression. }\end{array}$ & 108 \\
\hline Small bowel & ATG / tacrolimus & $\begin{array}{l}\text { - Biopsy-proven acute cellular rejection within } 60 \text { days of transplant was } \\
\text { associated with significantly higher mDC:pDC ratio. } \\
\text { No correlation was seen between DC subsets and tacrolimus blood } \\
\text { concentration }\end{array}$ & 113 \\
\hline Lung & $\begin{array}{l}\text { tacrolimus or CsA / MMF / } \\
\text { azithromycin or } \\
\text { azathioprine }\end{array}$ & $\begin{array}{l}\text { In healthy patients with no obliterative bronchiolitis: } \\
\text { - Monocyte derived-DC displayed upregulated IDO expression and } \\
\text { reduced CD83 and CD80 expression } \\
\text { - In ex vivo DC co-cultures: } \uparrow \text { autologous Treg, } \uparrow \text { IL-10; } \uparrow \text { CTLA-4 } \\
\text { expression; } \downarrow \text { ICOS and } \downarrow \text { CD28 expression. }\end{array}$ & 114 \\
\hline Kidney & $\begin{array}{l}\text { tacrolimus / MMF / steroids } \\
\text { or Campath-1 / tacrolimus }\end{array}$ & $\begin{array}{l}\text { Total peripheral DC counts we significantly reduced after Campath-1 } \\
\text { induction } \\
\text { - Campath-1- treated patients exhibited significantly lower mDC/pDC } \\
\text { ratio }\end{array}$ & 123 \\
\hline Kidney & $\begin{array}{l}\text { acrolimus / CsA / MMF / } \\
\text { rapamycin / steroids / } \\
\text { azathioprine }\end{array}$ & $\begin{array}{l}\text { On } \mathrm{mDC}\left(\mathrm{CD} 11 \mathrm{c}^{+} \mathrm{CD} 83^{+} \mathrm{CD} 40^{+}\right) \text {analysis following transplant: } \\
\text { - } \quad \text { Symptom-free patients late post-transplant had higher IL-10 } 0^{+} \mathrm{DC} \text { than } \\
\text { symptom-free recipients early post-transplant }\end{array}$ & 115 \\
\hline
\end{tabular}




\begin{tabular}{|c|c|c|c|}
\hline Transplant & Immunosuppression & DC profile $+/-T$ cell stimulatory capacity & Ref \\
\hline & & $\begin{array}{l}\text { IL-12+DC and IL-10+DC were higher when the dosage of CsA, } \\
\text { steroids, and MMF was reduced. }\end{array}$ & \\
\hline Kidney & $\begin{array}{l}\text { CTLA-4Ig / steroids / } \\
\text { MMF / basiliximab }\end{array}$ & $\begin{array}{l}\text { - Significantly higher HLA-G5 plasma levels in CTLA4-Ig- } \\
\text { treatedpatients than control groups. } \\
\text { Monocyte-derived DC were poor stimulators of alloreactive T cells in } \\
\text { comparison to control group and expressed significantly more } \\
\text { intracellular HLA-G than control group }\end{array}$ & 107 \\
\hline Kidney & $\begin{array}{l}\text { CsA or tacrolimus/ } \\
\text { rapamycin / steroids }\end{array}$ & 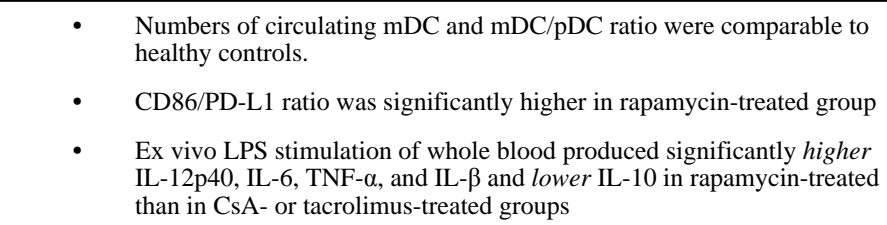 & 110,111 \\
\hline
\end{tabular}

ATG, anti-thymocyte globulin; CsA, Cyclosporine A; MMF, Mycophenolate mofetil; mDC, myeloid DC; pDC, plasmacytoid DC 